their paths in an unpredietable manner. Although Pickering's views were not generally accepted, they are difficult to disprove-even if they are equally difficult to prove; no instrumental equipment at present could definitely disprove the theory of some low form of life on the moon.

\section{High Altitude Research: Symposium in Gulmarg,} Kashmir

AT the meeting of the Council of the National Institute of Sciences of India, held in New Delhi in October last, it was decided to organize a symposium on "High Altitude Research" during May 27-28, at the Gulmarg Research Observatory, Kashmir (director, Prof. P. S. Gill). Gulmarg Observatory was selected because of its unique position. Situated at a height of $9,000 \mathrm{ft}$. above sea-level, it compares favourably with several outstanding high-altitudo laboratories elsewhere in the world. The site is also suitable as a base station for work at still higher altitudes up to $11,000 \mathrm{ft}$. at Khillan Marg, one hour distant, and up to 14,000 ft. at Apharvat, three hours distant. The geomagnetic latitude $\left(23^{\circ} 32^{\prime} \mathrm{N}\right.$.) and longitude $\left(75^{\circ} \mathrm{E}.\right)$ are of special significance in cosmic-ray measurement, for the latitude is that at which the most rapid cosmic-ray changes occur with changing latitude, and the longitude is close to that whore maximum effects of the Earth's magnetic field are observed. The symposium proper was held on May 28, the morning session being allotted to biological sciences, and the evening to physical sciences; but the boundary between the two sciences was never very sharp. In all, about seventy papers were read, and the proceedings will be published in the form of a bulletin by the National Institute of Seiences of India.

\section{Science Students in New Zealand}

THE Department of Scientific and Industrial Research of New Zealand has carried out a most valuable survey into the supply, quality and employ. ment of graduates in the various scientific disciplines in New Zealand. Included in the survey were 4,852 students $(4,068$ men and 784 women) who had begun university courses in science since 1950 (New Zealand: Department of Scientific and Industrial Research. Bulletin 113 : The Academic Record of Science Students in the University of New Zealand. By I. D. Dick, R. M. Williams and Dermot Straker. Pp. 64. (Wellington : Government Printer, 1955.) 6s. 6d.). Among the information collected was the length of study, the subjects studied and the marks obtained, the kind of degrees taken and the time taken to get them. A broad picture of the employment followed by the science graduates showed that about oneninth went into the Department of Scientific and Industrial Research, one-ninth into school-teaching, one-twelfth went overseas and one-thirteenth went into industry. Those who joined the staff of the University of Now Zealand were of high academic quality, as were those who went overseas; school teaching attracted fow with first-class honours degrees.

\section{Sodium in Empty Ether Bottles}

Mir. D. RAINY Brows, of J. F. Macfarlan and Co., Ltd., 8 Elstree Way, Boreham Wood, Herts, writes stating that bottles which have contained ether are returned to the firm from time to time containing traces of metallic sodium, presumably used to remove traces of water. There is a real risk of fire when such bottles are washcd. Although precautions are taken Messrs. Macfarlan have over a period of years had accidents, although fortunately none of them was serious. They therefore ask those who use sodium for drying ether to have special vessels for the purpose, or to ensure that no sodium is left in returned bottles.

\section{Petroleum Films Bureau}

Tere 1955 edition of the list of $35-\mathrm{mm}$. and 16-mm. documentary and instructional films issued by the Petroleum Films Bureau contains no fewer than forty-five additions to the previous catalogue. Among the new subjects available are "Ageless Iraq" ; "The Search for Oil" ; "Assam Oil Survey" ; "The Digboi Story"; "The Chemistry of Oil" ; "The Modern Oil Refinery"; "Red Ruin" or prevention of must; "Individual Aircraft Series", including the Comet, Valiant, Brabazon and Hawker Hunter. All 16-mm. films are 'non-flam' stock: 35-mm. films are 'flam' stock. Applications from educational establishments, scientific and technical societies, youth clubs and the like to borrow films should be made to the Petroleum Films Bureau, 29 New Bond Street, London, W.1.

\section{University of Liverpool}

THe following appointments in the University of Liverpool have been announced: Dr. J. D. Craggs, roader in electronic engineering, to the Robert Rankin chair of electronic engineering; Mr. D. L. Hughes, head of the Veterinary Science Division, Boots Pure Drug Co., Ltd., Nottingham, to the chair of veterinary pathology, in succession to Prof. R. T. Glover, who has become head of the Royal Veterinary College, London; Dr. F. D. S. Butement, a principal scientific officer at the Atomic Energy Research Establishment, Harwell, to the newly established post of senior lecturer in radiochemistry in the Department of Inorganic and Physical Chemistry.

\section{Announcements}

THe autumn conference of the British Occupational Hygiene Society will be held at the London School of Hygiene and Tropical Medicine on November 4; the subject will be "The Use and Abuse of Protective Equipment". Further information can be obtained from the Honorary Editor of the Society, Dr. C. N. Davies, London School of Hygiene and Tropical Medicine, Keppel Street, London, W.C.1.

IT has been the practice for some years past for members of the atomic energy projects of the three countries, the United Kingdom, the United States and Canada, to meet to discuss problems of common interest in the field of health and safety. It is proposed to hold another of these meotings at the Atomic Energy Research Establishment, Harwell, on September 19 and 20, specifically to consider pro. grammes of genetic research. In certain quarters this has been reported as an international conference on radiation-genetics; this is an over-statement of the cuse. As with previous meetings, this will not be a formal conference with prepared communications, but rather a working party to consider how best to plan future research and to integrate the available effort. It will differ from provious meetings in that a fow invitations have been sent to geneticists not actively connected with the three projects. With these as consultants, it is hoped that the most profitable programmes will be devised for future research. 